\title{
Seguridad Alimentaria: ¿Su cocina pasa la prueba?’1
}

\author{
Jennifer Hillan y Linda B. Bobroff ${ }^{2}$
}

Los adultos mayores corren un mayor riesgo de contraer enfermedades transmitidas por alimentos. Para ayudar a reducir el riesgo, es importante tener prácticas de manipulación de alimentos sanas. ¿Cómo se compara su cocina?

\section{La temperatura de mi refrigerador es:}

a. 50 grados Fahrenheit (10 grados Celsius).

b. 40 grados Fahrenheit (5 grados Celsius).

c. Nunca la he medido.

\section{Las sobras de guisado u otros alimentos con carne, pollo o pescado son:}

a. Enfriados a temperatura ambiente, después puestos en el refrigerador.

b. Puestos en el refrigerador dentro de dos horas después de que el alimento fue servido.

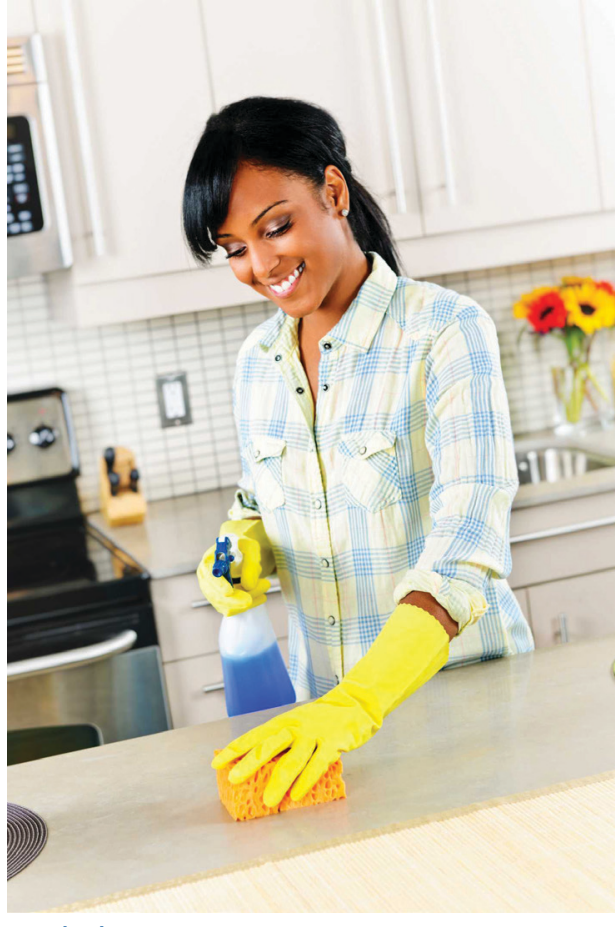

c. Dejados a temperatura ambiente hasta el próximo día y después puestos a refrigerar.

1. Este documento, FCS8801-Span, es uno de una serie de publicaciones del Departamento de Ciencias de la Familia, la Juventud y la Comunidad, Servicio de Extensión Cooperativa de la Florida, Instituto de Alimentos y Ciencias Agrícolas, Universidad de la Florida (UF/IFAS Extension). Fecha de primera publicación mayo 2010. Revisado enero 2018. Visite nuestro sitio web EDIS en $<$ http://edis.ifas.ufl.edu>.

2. Adaptado de "Can Your Kitchen Pass the Food Safety Test?" USDA/FDA Consumer Magazine, October 1995 por Jennifer Hillan, $\mathrm{MSH}, \mathrm{RD}$, LD/N, anterior educadora de nutrición ENAFS; y Linda B. Bobroff, PhD, RDN, profesora; Departamento de Ciencias de la Familia, la Juventud y la Comunidad; Instituto de Alimentos y Ciencias Agrícolas; Universidad de la Florida (UF/IFAS Extension); Gainesville, FL 32611. 
3. La última vez que el fregadero y el triturador de basura de mi cocina fueron desinfectados fue:
a. Entre los últimos días.
b. Varias semanas atrás.
c. No me recuerdo.

4. Descongelo la carne, el pollo y el pescado:
a. En el mesón.
b. En el refrigerador.
c. En el microondas.

5. La última vez que preparé masa para galletas en mi casa usando huevo crudo:
a. La probe en cuanto estaba mezclada.
b. La puse a refrigerar y después la probé.
c. No la probé hasta que las galletas estaban horneadas.

6. Si uso una tabla para cortar carne cruda, aves, o pescado y después la necesito para cortar otros alimentos, la tabla debe ser:
a. Re-usada como está.
b. Limpiada con un trapo húmedo.
c. Lavada con agua caliente y jabón.
d. Lavada con agua caliente y jabón y después desinfectada.

7. Yo limpio los mesones de mi cocina y otras superficies que están en contacto con alimentos con:
a. Agua.
b. Agua caliente y jabón.
c. Agua caliente y jabón, después con blan- queador u otro producto para desinfectar.

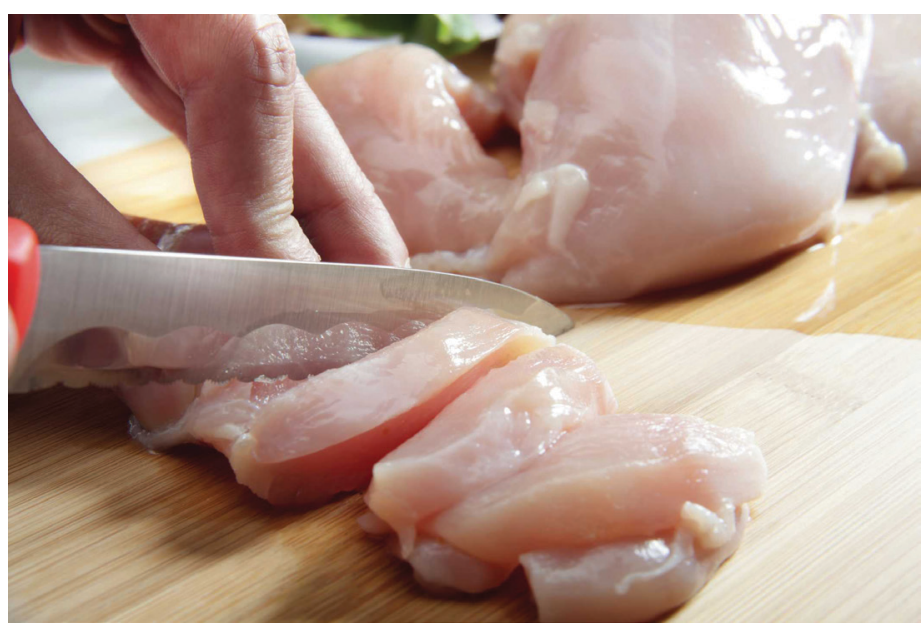

Créditos: iStockphoto 


\section{Respuestas}

1. La respuesta correcta es la B. Los refrigeradores deben estar a $40^{\circ} \mathrm{F}$ o menos para disminuir el crecimiento de la mayoría de bacterias. La temperatura no matará las bacterias, pero previene que se multipliquen, y entre menos bacterias hayan, las posibilidades de enfermarse son menores. Congelar a $0^{\circ} \mathrm{F}$ o menos detiene el crecimiento bacterial, pero no mata las bacterias que están ya presentes en los alimentos.

2. La respuesta correcta es la B. Los alimentos calientes deben ser refrigerados en cuanto sea posible, dentro de dos horas después de haber sido cocinados. Para mantener su refrigerador a temperaturas seguras (fíjese en la pregunta 1), no guarde alimentos muy calientes. Debe enfriar la comida rápidamente en platos de poca profundidad antes de ponerla en el refrigerador.

3. La respuesta correcta es la A.

El fregadero, el drenaje y la tubería deben ser desinfectadas periódicamente. Disuelva una cucharadita de blanqueador en un cuarto de galón (más o menos un litro) de agua y vacíelo por el drenaje.

4. Las respuestas correctas son la B y la C. También puede descongelar los alimentos en agua fría y limpia que sea cambiada cada 30 minutos. Si usa este método, asegúrese de no dejar los alimentos en el agua por más de dos horas. No descongele los alimentos en el mesón o en el fregadero sin agua fría. Las bacterias se podrían multiplicar rápidamente a temperatura ambiente. Comida descongelada en el microondas debe ser cocinada inmediatamente; no debe colocarse en el refrigerador para ser cocinada más tarde.

5. La respuesta correcta es la C.

Consumir alimentos que contengan huevo crudo o falto de cocción puede llevarlo a contraer enfermedades transmitidas por alimentos. Asegúrese de cocinar los alimentos que contienen huevo crudo a una temperatura de al menos $160^{\circ} \mathrm{F}$. Cocine los huevos hasta que la clara y la yema estén firmes, que no se muevan.

6. La respuesta correcta es la D.

Nunca deje que la carne cruda, las aves o el pescado (o sus jugos) toquen los otros alimentos. Lavar solo con trapos húmedos no remueve las bacterias. Lavar con agua y jabón puede que tampoco haga el trabajo bien. Después de lavar, usted puede desinfectar la tabla de cortar con una solución de una cucharadita de blanqueador disuelto en un cuarto de galón (más o menos un litro) de agua.

7. Las respuestas correctas son la B y la C. El agua caliente con jabón lo limpiará, pero el blanqueador y los productos comerciales de limpieza para la cocina lo desinfectarán y matarán algunas de las bacterias. 